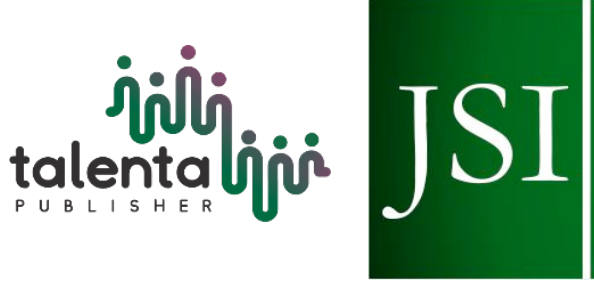

\title{
The Potential Study of Segenter Waterfall As a Tourist Destination in The Tahura Nuraksa
}

\author{
Hadijah Putri $^{\text {**, Andi Chairil Ichsan }}{ }^{1}$, and Budhy Setiawan ${ }^{1}$ \\ ${ }^{I}$ Major of Forestry, Faculty of Agriculture, Universitas Mataram, Jl. Majapahit No. 62, Mataram NTB, \\ Indonesia
}

\begin{abstract}
Nuraksa Tahura is an area that can develop as a tourist destination with its natural waterfall Segenter. For its development, the same effort was the need for the waterfall. This study aims to determine the feasibility of Segenter waterfalls, its development strategies, and future development solution. The research was conducted through data collection, observation, interviews, Focus Group Discussion. The data were analyzed using natural tourist attraction Guidelines of Director General of Forest Protection and Nature Conservation 2003 and SWOT analysis. The results of the research showed that Segenter waterfall is feasible to be used as a tourist destination. The development uses the SO strategy to utilize its opportunities with its own potential by the Nuraksa Tahura region.
\end{abstract}

Keyword: Development Strategy, Feasibility, Potency

Received 21 November 2019 | Revised 13 July 2020 | Accepted 26 August 2020

\section{Introduction}

West Nusa Tenggara (NTB) is one of the provinces with abundant biodiversity, natural view, flora, and fauna and has exotic cultural diversity. The current biodiversity and its exotic culture make West Nusa Tenggara (NTB) very potential for ecotourism development.

Ecotourism is a tour activity packaged in a professional, trained, and educational element as an economic sector/business, taking into account the cultural heritage, participation, and welfare of the local population and efforts to conserve natural resources environment [1]. Potential development is closely related to personality values and development by utilizing all the potential and beauty and natural wealth that exists and serve as objects of natural tourism attractions (ODTWA).

\footnotetext{
*Corresponding author: Major of Forestry, Faculty of Agriculture, Universitas Mataram, Jl. Majapahit No. 62, Mataram NTB, Indonesia

E-mail address: hadijahputri12@gmail.com 
According to the government rules No 10 of 2009 concerning tourism, ODTWA is anything that has a uniqueness, beauty, and value in the form of the diversity of natural wealth, culture, and human-made products that are the target or destination of tourist visits. As a product sold in the tourism market, ODTWA must have three main components: the destination's attraction, the facilities owned by the destination, and the accessibility of the destination. One of the conservation areas in NTB with high natural tourist attraction and natural conditions is the Taman Hutan Raya Nuraksa.

Tahura Nuraksa area is an area with high natural tourism potential. The condition of vegetation is still natural, with a variety of flora and fauna [2]. One of the tourism potentials areas in Tahura Nuraksa is Segenter Waterfall. This waterfall is the main attraction in the Nurura Tahura area.

Based on the above description, Tahura Nuraksa and Segenter Waterfall have s potential to be developed as natural tourism. However, for developing the tourism potential process, there are some supporting and inhibiting factors. Therefore or research was conducted to determine the feasibility of the waterfall and the supporting elements and inhibiting factors for the development of Segenter Waterfall and the development of the tourism solution to become a natural tourist attraction of interest.

\section{Research Methods}

This research was carried out from February to March 2019 in Tahura Nuraksa. Tahura Nuraksa is located in Kumbi Hamlet, Pakuan Village, Narmada, West Lombok. Tools and materials used were stationery, cameras, laptops, questionnaires, and ODTWA assessment tables. The method is a descriptive qualitative approach that is systematically reviewing the description related to the factual conditions and the object under study [3]. Observation, interviews did data collection, FGD is an in-depth interview conducted by researchers with a group of people at a time. The groups of people are not interviewed separately, but together in a meeting [4].

The location study was plotted using the purposive sampling method based on certain criteria [5]. One of the underlying criteria for the segenter is the priority tourism development areas by the local government through the TAHURA so that the availability of information related to this feasibility analysis is very needed as a basic data for the research.

The data obtained were analyzed using ADO-ODTWA Guidelines of Director General of Forest Protection and Nature Conservation 2003. According [6] states that assessment variables for the analyses consisted of attractiveness, accessibility, conditions around the area, accommodation and supporting infrastructure, and SWOT analysis. According to [7], SWOT analysis is a method used to formulate strategic factors in ecotourism development. 


\section{Results and Discussion}

\subsection{Feasibility Analysis of ADO-ODTWA in Tahura Nuraksa}

This research was conducted in the Taman Hutan Raya Nuraksa through direct observation and interviews with respondents. The study was conducted to find out the potential based on the Regional Analysis of Nature Tourism Object Operations Guidelines (ADO-ODTWA) DirectorGeneral of the modified PHKA 2003. Several elements were analyzed: attractiveness, accessibility, conditions around the area, accommodation, and supporting infrastructure. The results of the analysis can be seen in Table 1 .

Table 1 The result of assessment and analyses on Taman Hutan Raya Nuraksa

\begin{tabular}{llcccccc}
\hline No. & Variable & Wheight & Score & Score* & $\begin{array}{l}\text { Maksimum } \\
\text { score** }^{* *}\end{array}$ & $\begin{array}{l}\text { Indeks } \\
(\mathbf{\%}) * * *\end{array}$ & Result \\
\hline 1. & Attractiveness & 6 & 130 & 780 & 900 & 86.67 & feasible \\
2. & $\begin{array}{l}\text { Accessibility } \\
\text { Conditions around }\end{array}$ & 5 & 65 & 325 & 400 & 81.25 & feasible \\
3. & 5 & 45 & 225 & 300 & 75 & feasible \\
the Area & Accommodation & 3 & 5 & 15 & 15 & 100 & feasible \\
5. & $\begin{array}{l}\text { Facilities and } \\
\text { infrastructure }\end{array}$ & 3 & 30 & 90 & 120 & 83.33 & feasible \\
\hline
\end{tabular}

level of eligibility $* * * *$

$83.59 \%$

Notice $=*$ the result of multiplication between weight and score, $* *$ the number of elements multiplied by the highest total score, $* * *$ the result of multiplication between scores times 100 divided by the maximum score, $* * * *$ the result of adding the index divided by the number of elements

Table 1 shows that the Taman Hutan Raya Nuraksa can be developed as a tourism destination with an average of $83.59 \%$. Each variable also indicates a percentage that fulfills the feasibility criteria, although some variables such as facilities and access to locations still need to improve. It can be concluded that a group that manages tourism like conscious tourism groups were required so that its management can be carried out optimally. Improvement and development are efforts to improve the quality of the marketing of tourism products offered. It is also in line with [8], which states that a marketing mix is a tool that can be used in implementing the chosen market improvement strategy (both product, price, location, place, and promotion) and other businesses in delivering value. Attraction, advertising, and infrastructure play an essential role in developing tourism. An exemplary buildup causes these tourist attractions to be widely known by tourists.

\subsection{Supporting factors and obstacle factors for tourism development}

\section{A. Supporting factors}

Supporting factor is something that can encourage or support activity. The area that is a tourist destination must have a displayed attraction. According to [9], developed a tourist attraction capital or a source of tourism was needed. 
Table 2 Supporting Factor

\begin{tabular}{ll}
\hline \multicolumn{1}{c}{ Aspect } & \multicolumn{1}{c}{ Supporting factors } \\
\hline Attractiveness & - Still natural \\
Accessibility & - Reachable \\
Education & - Can be used as a research location related to flora and fauna \\
\hline
\end{tabular}

\section{B. Obstacle factor}

Obstacle factors are things that hinder the management of Segenter Waterfall. The inhibiting factors for developing Segenter Waterfall can be seen in Table 3.

Table 3 Obstacle Factor

\begin{tabular}{ll}
\hline \multicolumn{1}{c}{ Aspect } & \multicolumn{1}{c}{ Obstacle factors } \\
\hline Marketing & - Still not optimal \\
Facilities and infrastructure & - Needs to be added and Improved \\
Management & - Management has not been maximized. \\
\hline
\end{tabular}

\subsection{Analysis of Development Strategies with SWOT Analysis}

According to [10-12], SWOT analysis is a strategic plan used to find alternative strategies that can be used in ecotourism development, which can be done by evaluating the strengths, weaknesses, opportunities, and threats.

\section{A. Internal Strategy Factor Evaluation}

Strength Analysis

Table 4 Strength Analysis

\begin{tabular}{|c|c|c|c|c|}
\hline Category & Internal Factor Strategies & Rating & Weight & Score \\
\hline \multirow[t]{6}{*}{ Strength } & $\begin{array}{l}\text { 1. Segenter Waterfall is still natural } \\
\text { with cool air and } \\
\text { beautiful scenery }\end{array}$ & 4 & 0.5 & 2 \\
\hline & $\begin{array}{l}\text { 2. There are supporting facilities and } \\
\text { infrastructure around the area such } \\
\text { as changing rooms, information } \\
\text { boards, stairs, and photo spots }\end{array}$ & 4 & 0.25 & 1 \\
\hline & $\begin{array}{l}\text { 3. Counseling and socialization are } \\
\text { often done so that people } \\
\text { understand the rules in the } \\
\text { conservation area }\end{array}$ & 3 & 0.05 & 0.15 \\
\hline & $\begin{array}{l}\text { 4. Routine patrols continue to be } \\
\text { carried out } 1 \times 24 \text { hours }\end{array}$ & 3 & 0.1 & 0.3 \\
\hline & $\begin{array}{l}\text { 5. Ticket prices are relatively low } \\
\text { both local and foreign tourists }\end{array}$ & 3 & 0.1 & 0.3 \\
\hline & & Total & & \\
\hline
\end{tabular}


Based on Table 4, the highest strength category is 0.5. It shows that the main strength factor in ecotourism development is the Segenter Waterfall is still natural with cold air and beautiful scenery. The total value in the strength analysis is 3.75 . According to [13], tourist attraction has its strengths as a component of tourism products because it can generate tourists' motivation and attract tourists to travel. With the attraction available in the Segenter Waterfall area, it will attract tourists to visit the location.

Weakness Analysis

Table 5 Weakness Analysis

\begin{tabular}{|c|c|c|c|c|}
\hline Category & Internal Factor Strategies & Rating & Weight & Score \\
\hline \multirow[t]{6}{*}{ Weakness } & $\begin{array}{l}\text { 1. Segenter Waterfall tourism marketing is } \\
\text { not optimal }\end{array}$ & 2 & 0.4 & 0.8 \\
\hline & $\begin{array}{l}\text { 2. Roads in the area of tourism are still } \\
\text { inadequate and lack of maintenance of } \\
\text { existing infrastructure }\end{array}$ & 2 & 0.2 & 0.4 \\
\hline & $\begin{array}{l}\text { 3. There is no mosque in the waterfall area } \\
\text { and many facilities and infrastructure } \\
\text { damaged by landslides }\end{array}$ & 1 & 0.05 & 0.05 \\
\hline & $\begin{array}{l}\text { 4. Management has not been carried out in } \\
\text { a professional manner where no } \\
\text { institution specifically manages tourism } \\
\text { such as tourism awareness groups }\end{array}$ & 2 & 0.1 & 0.2 \\
\hline & $\begin{array}{l}\text { 5. The permanent building is not allowed } \\
\text { because it is a conservation area }\end{array}$ & 3 & 0.1 & 0.3 \\
\hline & & & Total & 1.75 \\
\hline
\end{tabular}

Based on Table 5, the highest value is 0.4 , which is tourism marketing that is still not optimal. This shows that the promotion process is still lacking, so many tourists do not know the location of the tour. The total score from this weakness analysis is 1.75 . It means that there are development efforts still needed in some elements of tourist attractions to optimize both in terms of infrastructure and management in the management of the region.

\section{B. Evaluation of External Factors}

Opportunity analysis

Based on Table 6, the highest value is 0.35 . Access to tourist sites is easy to reach and relatively close. This is proven by the location of Tahura Nuraksa, which can be reached within \pm 1 hour with the right road conditions so that it is straightforward to get. For a total score of 3.95 , which shows that the chances of supporting the waterfall area's development are relatively high. 
Table 6 Opportunity analysis

\begin{tabular}{|c|c|c|c|c|}
\hline Category & External Factor Strategies & Rating & Weight & Score \\
\hline \multirow[t]{6}{*}{ Opportunity } & $\begin{array}{l}\text { 1. The location of Tahura is close to } \\
\text { the tourist sites in Sesaot so that } \\
\text { visitors can also enjoy the beauty of } \\
\text { other nature namely waterfalls }\end{array}$ & 4 & 0.1 & 0.4 \\
\hline & $\begin{array}{l}\text { 2. Access from the capital city to the } \\
\text { waterfall is easy to reach, and the } \\
\text { distance from the capital is } \\
\text { relatively close }\end{array}$ & 4 & 0.35 & 1.4 \\
\hline & $\begin{array}{l}\text { 3. Can be used as a research location } \\
\text { related to flora and fauna }\end{array}$ & 4 & 0.3 & 1.2 \\
\hline & $\begin{array}{l}\text { 4. Many community resources are } \\
\text { made into labor (Pamhut) }\end{array}$ & 4 & 0.2 & 0.8 \\
\hline & $\begin{array}{l}\text { 5. Many visitors come to the waterfalls } \\
\text { on holidays }\end{array}$ & 3 & 0.05 & 0.15 \\
\hline & & & Total & 3.95 \\
\hline
\end{tabular}

\section{Threat Analysis}

Based on threat analysis, the highest value is 0.4 obtained from the absence of supporting facilities around the area such as banks, shopping centers, and lodging variable. So that foreign visitors must stay at home residents. Based on the results of interviews and observations, there are no lodgings and other infrastructure around the area so that if there are foreign visitors who come must bring tents or stay at the people's homes.

Table 7 Threat Analysis

\begin{tabular}{|c|c|c|c|c|}
\hline Category & External Factor Strategies & Rating & Weight & Score \\
\hline \multirow[t]{5}{*}{ Threat } & 1. Other attractions are more interesting & 3 & 0.05 & 0.15 \\
\hline & $\begin{array}{l}\text { 2. There is no road marking (directions) } \\
\text { along the road to the waterfall }\end{array}$ & 2 & 0.15 & 0.3 \\
\hline & 3. The telephone network is not good & 1 & 0.3 & 0.3 \\
\hline & $\begin{array}{l}\text { 4. Education in the surrounding community } \\
\text { is still relatively low }\end{array}$ & 2 & 0.1 & 0.2 \\
\hline & $\begin{array}{l}\text { 5. There are no supporting facilities around } \\
\text { the area, such as banks, shopping centers, } \\
\text { and lodging. So that foreign visitors must } \\
\text { stay at home residents }\end{array}$ & 1 & 0.4 & 0.4 \\
\hline
\end{tabular}

Total 1.35

Based on the analysis, the $\mathrm{X}$ value is 1 , and the $\mathrm{Y}$ value is 1.3. Thus it can be determined that Segenter Waterfall is in the first quadrant of the SWOT analysis. Figure 1 presents the position of Segenter Waterfall in the SWOT analysis quadrant. 


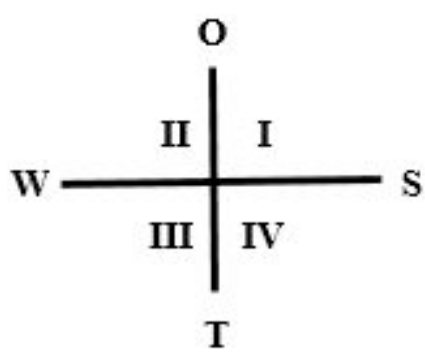

Figure 1 Quadrant SWOT

The Formula: $(X, Y)=(S-W),(O-T)$

$$
\begin{aligned}
& =((3.75-1.75) / 2),((3.95-1.4) / 2) \\
& =(1,1.3)
\end{aligned}
$$

Figure 1 shows that Segenter Waterfall is in a favorable situation where Segenter Waterfall has opportunities and strengths to take advantage of its opportunities [7].

Based on Table 8, the highest score is the SO strategy in the form of maintaining and developing the potential of unspoiled forests to be more desirable and sustainable and utilizing the location of the Tahura Nuraksa near the capital to attract tourists.

C. Formulation of development Strategy

Table 8 SWOT Matrix

\begin{tabular}{lll}
\hline \multicolumn{1}{c}{ Strengths } & \multicolumn{1}{c}{ Weakness } \\
\hline \multicolumn{1}{c}{ Internal factors } \\
\hline $\begin{array}{l}\text { Segenter Waterfall is still natural with } \\
\text { cold air and beautiful scenery }\end{array}$ & 1. & $\begin{array}{l}\text { Segenter Waterfall tourism marketing is } \\
\text { not optimal }\end{array}$ \\
$\begin{array}{l}\text { There are supporting facilities and } \\
\text { infrastructure around the area such as } \\
\text { changing rooms, information boards, } \\
\text { stairs, and photo spots }\end{array}$ & 2. & $\begin{array}{l}\text { Roads in the area of attractions are still } \\
\text { inadequate and lack of maintenance of } \\
\text { existing infrastructure }\end{array}$ \\
$\begin{array}{l}\text { Counseling and socialization are often } \\
\text { done so that people understand the rules } \\
\text { in the conservation area }\end{array}$ & 3. & $\begin{array}{l}\text { There is no mosque in the waterfall area } \\
\text { and many facilities and infrastructure } \\
\text { damaged by landslides }\end{array}$ \\
Regular patrols will continue for 1x24 & 4. $\begin{array}{l}\text { Management has not been carried out in a } \\
\text { professional manner where no institution } \\
\text { Ticket prices are relatively low both }\end{array}$ & $\begin{array}{l}\text { specifically manages tourism such as } \\
\text { tourism awareness }\end{array}$ \\
local and foreign tourists & 5. & $\begin{array}{l}\text { The permanent building is not allowed } \\
\text { because it is a conservation area }\end{array}$ \\
\hline
\end{tabular}


External Factors

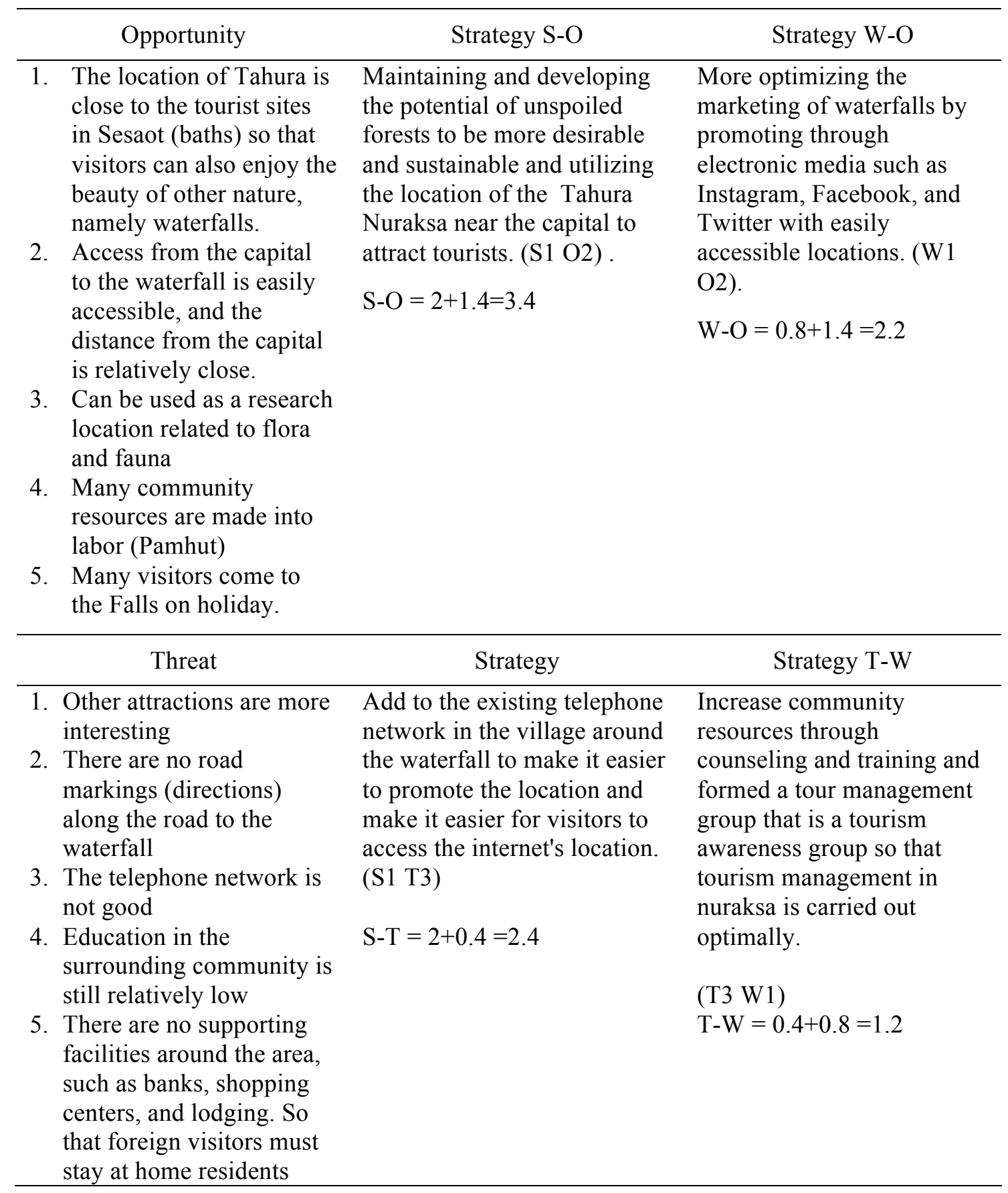

According to [14] in introducing new tours and finding out how the attraction of tourists to visit, there must be a strategy from the manager to introduce and maintain prospective tourists. Strategies in management can be seen in the SWOT Matrix table, where the highest strategy is SO strategy of 3.4. [15]-[17] states that this SO strategy is a strategy that is in a favorable situation where this tourist site has considerable strength and opportunities in development by increasing the strengths it has and taking advantage of existing opportunities. The strategy used in developing this waterfall is based on the results of the SWOT Matrix, namely maintaining and developing the potential of forests to be more desirable and sustainable and utilizing the location of the Tahura Nuraksa near the capital to attract tourists. 
Besides the beauty of tourism, accessibility is an essential component for tourists in traveling. If access is good, tourists will prefer to visit the location. According to [18], tourism accessibility is a facility that makes it easy for tourists to reach tourist destinations. According to [13],[19], a complete set of facilities is needed to serve tourists' needs to enjoy the trip-support for facilities and infrastructure to facilitate and provide comfort to visitors to tourist sites. The increasing facilities and infrastructure and quality of service in the Waterfall attractions are among the reasons for the increasing number of visitors who come to travel into the region.

In the development of ecotourism, community participation is also important. In tourism management, it is necessary to involve the surrounding community to employ the surrounding community to increase income for the community around the area. According to [20] stated that without the participation and direct involvement of local communities in tourism development activities in a site where there are potential resources to be developed, it would be quite difficult for them to develop. The participation referred to in this matter is maintaining parking, security, and forming tourism awareness groups so that the waterfall management can be maximized. In the Tahura Nurkasa area, the management has involved the community for parking and protecting the area because it was carried out by Pamhut, where the Pamhut personnel is the people around the area.

\section{Conclusion}

Taman Hutan Raya (Tahura) Nuraksa has natural tourism potential with a feasibility value of $83.6 \%$. The supporting factors in the development of Segenter Waterfall are its natural view, easily accessible, and can be used as research locations. While the inhibiting factors are marketing that is still not optimal, facilities, and infrastructure that have been damaged need to be replaced, and management is still not optimal. Strategies or efforts to develop Segenter Waterfall tourism can be made using the SO (Strength-Opportunity) strategy.

\section{REFERENCES}

[1] Nugroho, I., Ekowisata Dan Pembangunan Berkelanjutan, Pustaka Pelajar, Yogyakarta. 2011.

[2] Balai Tahura Nuraksa, Tahura Nuraksa Block Structuring Design Document, Mataram, Balai Tahura Nuraksa, 2018.

[3] Sugiyono, Metode Penelitian Kuantitatif, Kualitatif Dan R\&D, Alfabeta, Bandung, 2017.

[4] Afrizal, Qualitative Research Method (an effort to support the use of qualitative research in various disciplines), PT Raja Grafindo Persada, Jakarta, 2016.

[5] Siregar, Syofian, Metode penelitian Kuantitatif, PT Fajar Interpratama mandiri, Jakarta, 2017.

[6] Andriani, P., "Analysis of the feasibility and strategy of developing natural tourist attraction objects at the Kerandangan nature tourism park," dissertation, Mataram University, 2018.

[7] Rangkuti, F., Analisis SWOT Teknik Membedah Kasus Bisnis (Reorientasi Konsep Perencanaan Strategis untuk Menghadapi Abad 21), PT. Gramedia Pustaka Utama, Jakarta, 2017. 
[8] Lovelock, C., \& L.K. Wringht, Manajemen Pemasaran Jasa, PT. Indeks. Gramedia, Jakarta, 2007.

[9] Mellu., et al., "Supporting and Inhibiting Factor Analysis of Tourism Objects Development in Palelo Bola Natural Tourism Object, Central Mollo District, South Central Timor Regency," Journal Of Management, vol. 7, no. 2. 2018.

[10] Atmoko, T., "Strategy for developing ecotourism in the bekantan habitat (Nasalis larvatus Wurmb.) in Kuala Samboja, East Kalimantan," Jurnal Penelitian Hutan dan Konservasi Alam, vol. 7, no. 4, pp. 425-437. 2010.

[11] Fahrian, H. H., Putro, S. P., Muhammad, F., "Potential Ecotourism in the Mangrove Region, Mororejo Village, Kendal Regency," Biosaintifika: Journal of Biology \& Biology Education, vol. 7, no. 2, 2015.

[12] Khoiri, F., Utomo, B., Lesmana, I., "Feasibility Analysis of Mangrove Ecotourism Development in Muara Indah Beach, Labu Beach District, Deli Serdang Regency," AQUACOASTMARINE, vol. 2, no. 1, 2014.

[13] Isdarmanto, Dasar-dasar Kepariwisataan dan Pengelolaan Destinasi Pariwisata, Gerbang Media Aksara dan STIPRAM Yogyakarta, Yogyakarta, 2017.

[14] Kirom., et al., "Determinants of Cultural Tourism Attraction and Its Effect on Tourist Satisfaction," Jurnal pendidikan teori, penelitian, dan pengembangan, vol. 1, no 3, 2016.

[15] Pantiyasa, I. W., "Community Based Tourism Development in Community Empowerment (Case Study in Bedulu Village, Blah Batuh, Gianyar)," Jurnal Ilmiah Hospitality management, vol. 1, no. 2, 2018.

[16] Satria, D., "Strategies for developing ecotourism based on the local economy in the context of poverty alleviation programs in Malang Regency," Journal of Indonesian Applied Economics, vol. 3, no. 1, 2009.

[17] Abiyoga, R., Suryanti, S., \& Muskananfola, M. R., "Development Strategy for Mangrove Conservation Activities in Bedono Village, Demak Regency," Management of Aquatic Resources Journal, vol. 6, no. 3, pp. 293-301. 2018.

[18] Nawangsari., Dyanita, Muryani., Chatarina., Utomowati., Rahning, "Development of Coastal Tourism in Watu Karung Village and Sendang Village in Pactan Regency," Jurnal GeoEko, vol 4, no 1, 2018.

[19] Suwantoro, Gamal, Dasar-dasar Pariwisata, Yogyakarta, Andi, 2004.

[20] Devy, et al., "Development of Natural Tourism Objects and Attractions as a Tourism destination in Karanganyar Regency, Sebelas Maret University, Surakarta," Jurnal Sosiologi DILEMA, vol 32, no.1, 2017. 